\title{
An Assessment of Phytoplankton Population and Seasonal Variation in Lendi River, District Nanded, Maharashtra, India
}

\author{
Bimbisar D. Waghmare ${ }^{1}$, A. N. Kulkarni ${ }^{2}$ \\ ${ }^{1,2}$ Department of Fishery Science, N.E.S. Science College, Nanded (M.S.) India
}

\begin{abstract}
Lendi River is one of the tributary of river Manar, originates at Malkapur dist. Latur and joins to river Manar at Degloor, dist Nanded. Water of this Semi-perennial river is used to perform various activities such as industrial, irrigation, fisheries and human activities. A total of 20 species of phytoplankton were recorded during the present study period. These include 13 species of Chlorophyceae, 4 species of Cyanophyceae and 3 species of Bacillariophyceae. Plankton samples were collected at regular intervals of one month at 3 stations from July 2010 to June 2011.
\end{abstract}

Keywords: Phytoplankton, Seasonal Variation, Population, Lendi, River, Nanded.

\section{Introduction}

Plankton of rivers varies according to chemistry of the water (including gases and nutrients), temperature and amount of suspended matter, all of which are related to elevation gradient, surface wind and current affect the horizontal distribution of plankton. Phytoplankton dynamics have been studied extensively in lentic fresh waters (lakes and reservoirs), yet comparatively little research has focused on lotic waters (rivers). The investigations in river planktons are scanty due to practical difficulties in the survey and sampling of flowing water. Phytoplanktons are microscopic single celled aquatic plants forming the prime component in the food chain of an aquatic ecosystem. Some phytoplankton species are also often used as good indicators of water quality including pollution Rajashree (1993). The phytoplankton consist of the assemblage of small plants having no or very limited power of locomotion; they are therefore more or less subject to distribution by water movements. Phytoplanktons are largely restricted to lentic waters and large rivers with relatively low current velocities. In the present study phytoplankton population and seasonal variations in Lendi River are reported.

Several investigators worked on phytoplankton population viz., Mathivanan et.al., (2007) assessed plankton population of Cauvery river with reference to pollution. Ingole et.al., (2010) observed phytoplankton group at Majalgaon reservoir on Sindphana river, district Beed (M.S.) such as Chlorophyceae, Bacillariophyceae, Cynophyceae and Euglenophyceae in which 33genera were recorded. Sharma et.al., (2011) studied the diversity and seasonal abundance of phytoplankton of river Narmada, Madhya Pradesh (India) and found green algae (Chlorophyceae) diatoms (Bacillariophyceae) and the blue green algae (Myxophyceae). Suresh et.al., (2011) worked on phytoplankton dynamics and seasonal variation in Tungabhadra river. Vasanthkumar and Vijaykumar (2011) studied diversity and seasonal fluctuation of phytoplankton in Bheema River. An assessment of seasonal variation in phytoplankton community of Mahi river (India) were done by Sharma and Bhardwaj (2011) obtained results are such as the dominant group among phytoplankton community were Blue green algae and diatoms. Annalakshmi and Amsath (2012) investigated the composition, abundance, frequency of occurrence and diversity of net phytoplankton species inhabiting in river Cauvery and its tributaries river Arasalar at Kumbakonam area. Ramesha and Sophia (2013) investigated plankton species composition and diversity for a period of 14 months in the river Seeta, the Western Ghats, India. A total of 4 phytoplankton divisions were recorded during the study period. Kamble et.al., (2013) studied of phytoplankton in river Manjra Near Kallam. The phytoplankton communities of the present water body were represented mainly by (4) four groups of algae such as Bacillariophyceae, Chlorophyceae, Cyanophyceae and Euglenophyceae.

\section{Material \& Methods}

Study Area: For the study of phytoplankton population and seasonal variation in river Lendi three sampling stations (S-I Mukramabad, S-II Gonegaon \& S-III Bahegaon road) were selected on the right bank of river Lendi, out of them two stations are in Mukhed taluka and one station is in Degloor taluka, district Nanded. Station-I: Mukramabad: This station is located at the height of 394 meter above M.S.L. in between the latitude $18^{\circ} 28^{\prime} \&$ 44.33"N and longitude $77^{\circ} 21^{\prime} \& 58.20 " E$. Station-II: Gonegaon: This station is located at the height of 384 meter above M.S.L. in between latitude $18^{\circ} 31^{\prime} \& 13.63^{\prime \prime} \mathrm{N}$ and longitude $77^{\circ} 25^{\prime} \& 5.38^{\prime \prime} E$. Station is 6 to $7 \mathrm{~km}$ away from station-I. Station-III: Bahegaon Road (Degloor): This station is located at the height of 363 meter above M.S.L. in between latitude $18^{\circ} 32^{\prime} \& 41.32 " \mathrm{~N}$ and longitude $77^{\circ} 33^{\prime} \& 28.07^{\prime \prime} \mathrm{E}$. It is $10 \mathrm{~km}$ away from station-II.

Collection, Preservation and Identification of Phytoplankton samples: Plankton net was made by using nylon bolting cloth having mesh size of 60 micro meters used for the collection of plankton samples. 50 litres of water was sieved every time through the net. Samples were collected and preserved in 5\% formalin for 


\section{International Journal of Science and Research (IJSR) \\ ISSN (Online): 2319-7064}

Index Copernicus Value (2013): 6.14 | Impact Factor (2014): 5.611

microscopic identification as per Trivedy \& Goel, (1986) In the laboratory plankton slides were prepared for identification under compound microscope. The identified Phytoplankton were photographed with the help of 5 megapixel digital camera. The planktons were identified to species level as per the guidelines given by Gupta (2012), Gupta (2012) and Kodakar (1992).

Detailed analysis of phytoplankton population was done by estimating the number of each species. Preserved samples were mixed uniformly by gentle inversion and then exactly $1 \mathrm{ml}$ of the sample was pipette out into the $S$ $\mathrm{R}$ cell for analysis. The Sedgwick-Rafter cell of $50 \times 20 \mathrm{x}$ $1 \mathrm{~mm}$ is used for plankton counting. It is covered by a relatively thick cover slip and is calibrated to contain exactly $1.0 \mathrm{ml}$

\section{Results \& Discussion}

The phytoplanktons of river Lendi at three stations are found in three classes Cyanophyceae (Blue green algae), Chlorophyceae (Green algae) and Bacillariophyceae (Diatoms). In class Cyanophyceae phytoplankton are found in 3 orders i.e. Chroococcales, Oscillatoriales and Nostocales. Class Chlorophyceae is the largest class which shows 6 orders i.e. Oedogoniales, Chlorococcales, Zygnematales, Chlamydomonadaies, Chlorellales and Ulotrichales \& from class Bacillariophyceae 3 orders were identified that are Pennales, Fragilariales and Rhizosoleniales (Plate No. I).

\section{Station-I}

The identified phytoplanktons at this station belong to Class Cyanophyceae, Chlorophyceae and Bacillariophyceae. In the Cyanophyceae 4 species were identified and were included in order Chroococcales of (2 sp.), Oscillatoriales of (1 sp.) and Nostocales of (1 sp.). In class Chlorophyceae 8 species were identified from 5 order i.e. Oedogoniales (1 sp.), Zygnematales (3 sp.), Chlamydomonadaies (2 sp.), Chlorellales (1 sp.) and Ulotrichales (1 sp.). In class Bacillariophyceae 2 species were identified viz. Fragilariales (1 1 sp.) and Rhizosoleniales (1 sp.) (Table No. 1).

Monthly occurrence of phytoplanktons species at Station-I are depicted in Figure No. 1. The average number of species of phytoplanktons encountered from station-I are 28 out of which, 9 specie were belong to Cyanophyceae, 13 species to Chlorophyceae and 6 species to Bacillariophyceae. Total phytoplankton population density ranged from 15 (July) to 43 (April). The annual average percentage composition of different groups of phytoplanktons revealed to contribute nearly $32 \%$ of Cyanophyceae, $47 \%$ of Chlorophyceae and $21 \%$ of Bacillariophyceae.

\section{Station-II}

The identified phytoplankton at this station belongs to Class, Chlorophyceae and Bacillariophyceae. In class Chlorophyceae 5 species were identified from 4 order viz. Oedogoniales (1 $\mathrm{sp}$.$) , Chlorococcales (2 sp.),$ Zygnematales (1 sp.) and Chlamydomonadaies (1 sp.). In Bacillariophyceae 4 species were identified from 3 orders i.e. Pennales (1 $\quad$ sp.), Fragilariales $\left(\begin{array}{lll}2 & \text { sp. }) \text { and }\end{array}\right.$ Rhizosoleniales (1 sp.) (Table No. 1).

A total number of 9 species of phytoplankton belonging to Chlorophyceae and Bacillariophyceae identified and are presented in station-II. The changes in the total population density of different phytoplankton groups and their month wise percentage composition depicted in Figure No. 2. The maximum density of 19 organisms $/ \mathrm{ml}$ was observed during November, 2010 where as the minimum of 6 organisms/ml was observed during August, 2010. The annual average percentage composition of different groups of phytoplanktons revealed to contribute nearly $62 \%$ of Chlorophyceae, and $38 \%$ of Bacillariophyceae.

\section{Station-III}

The identified phytoplankton at this station belongs to Class Cyanophyceae, Chlorophyceae and Bacillariophyceae. In the class Cyanophyceae 4 species identified in order Chroococcales of (2 sp.), Oscillatoriales of (1 sp.) and Nostocales of (1 sp.). In class Chlorophyceae 7 species identified from 6 orders such as Oedogoniales (1 $\quad$ sp.), Chlorococcales (1 1 sp.), Zygnematales (2 sp.), Chlamydomonadaies (1 sp.), Chlorellales (1 sp.) and Ulotrichales (1 sp.). From the class Bacillariophyceae 5 species identified in 3 orders viz. Pennales (2 sp.), Fragilariales (2 sp.) and Rhizosoleniales (1 sp.) (Table No. 1).

The quantitative monthly occurrences of phytoplanktons species at Station-III are given in the Figure No. 3. The average numbers of species of phytoplanktons counted from station-III were 36 of which, 10 specimens belonged to Cyanophyceae, 14 to Chlorophyceae and 12 to Bacillariophyceae. Total phytoplankton population density ranged from 26 (April) to 48 (June). The annual average percentage composition of different groups of phytoplanktons revealed to contribute nearly $28 \%$ Cyanophyceae, $39 \%$ Chlorophyceae and $33 \%$ Bacillariophyceae.

In the present study Chlorophyceae population was most abundant followed by Bacillariophyceae and Cyanophyceae. Similar finding were reported by Mishra et.al., (2010) and observed 30 species of phytoplankton belonging to Chlorophyceae (10 species), Bacillariophyceae (11 species), Cyanophyceae (6 species) and Dinophyceae (3 species) from Dhaura and Baigul reservoirs. Suresh et.al., (2011) observed 64 species of phytoplankton of which 23 belong to Chlorophyceae, 18 Cyanophyceae, 14 Bacillariophyceae and 9 Euglenophyceae in river Tungabhadra. The annual periodicity shows Chlorophyceae dominated by 35.29 and $36.67 \%$ of the total phytoplankton population. Annalakshmi and Amsath (2012) studied annual phytoplankton of the river Cauvery consisted of $33.82 \%$ Chlorophyceae (Green algae), 27.94\% Bacillariophyceae (Diatoms), 32.35\% Cyanophyceae (Blue green algae), and $5.88 \%$ of Euglenophyceae.

In the present investigation, maximum number of phytoplankton observed in April, May and June while minimum in July, August \& September at 3 stations of river Lendi. Tripathy and Pandey (1990) observed

\section{Volume 4 Issue 12, December 2015}




\section{International Journal of Science and Research (IJSR) \\ ISSN (Online): 2319-7064}

Index Copernicus Value (2013): 6.14 | Impact Factor (2014): 5.611

maximum number of diatoms during monsoon and summer. Mathivanan et.al., (2007) reported that phytoplankton production was dependent upon temperature, turbidity and nutrients. Phytoplankton fluctuates monthly and its productivity was high during June and low during December. Rashid and Pandit (2008) in Sindh river and Ramesha and Sophia (2013) in Seeta river have observed that the peaks of phytoplankton occurred at different period in different years.

In the present study, the phytoplankton fluctuates monthly and its productivity was high during summer and low during rainy season as evidenced earlier by Mishra et.al., (2010), Krishnamoorthy et.al., (2007) and Shinde et.al., (2012). Banakar et.al., (2005) reported the peak of phytoplankton during April while lowest peak in July and August in village pond at Imalia (Vidisha) India. The productivity of phytoplankton might be due to the grazing effect by zooplankton and fishes as evidenced earlier by Mathivanan et.al., (2007) and Kamble et.al., (2013). Low density phytoplankton recorded during rainy season may be possibility is due to dilution by the rainy water coupled with other unfavourable environmental conditions. Laskar and Gupta (2009) reported minimum density of phytoplankton during monsoon and maximum during summer in Chatla lake, Assam. Shinde et.al., (2012) also reported similar observation in Harsool-Savangi dam, Aurangabad, India.

In general at all the stations the quantity of phytoplankton was very low from July to October. This may be due to heavy rain and flush of rain water in rainy season.

\section{Acknowledgement}

The authors are thankful to Principal, N.E.S. Science College, Nanded for providing laboratory \& library facilities. The first author is thankful to UGC for financial support and encouragement through awarding Maulana Azad National Fellowship for Minority Candidates (2009).

\section{References}

[1] Annalakshmi G. and A. Amsath (2012): Studies on the hydrobiology of river Cauvery and its tirbutaries Arasalar from Kumbakonam region (Tamil Nadu, India) with reference to phytoplankton. International Journal of Plant, Animal and Environmental Sciences, Vol. 2(2): 37-46p.

[2] Banakar A.B., S. Manjappa, B.R. Kiran, E.T. Pullaiah and M. Ravikumar (2005): Phytoplankton diversity in relation to abiotic factors in Chandravalli Lake at Chitradurga, Karnataka. Journal of Aquatic Biology, 20: 25-30p.

[3] Gupta P. (2012): Algae of India, Vol.1- A check list of Cyanoproeryota (Cyanophyceae). Published By: Botanical Survey of India, 160p.

[4] Gupta R.K. (2012): Algae of India, Vol.2- A check list of Cyanoproeryota (Cyanophyceae). Published By: Botanical Survey of India, 428p.

[5] Ingole S.B., Naik S.R. and Kadam G.A. (2010): Study of Phytoplankton of Freshwater reservoir at
Majalgaon on Sindphana River district Beed (M.S). International Research Journal, Vol. 1(13): 87-88p.

[6] Kamble S., Bhagwan H.K. and Patil B.Y. (2013): The study of phytoplankton in River Manjara near Kallam, Tal. Kallam, Dist. Osmanabad (MS) India. Trends in Life Sciences An International PeerReviewed Journal, Vol. 2(1): 21-24p.

[7] Kodakar M.S. (1992): Methodology for Water Analysis, Physico-chemical, Biological and Microbiological. India Association of Aquatic Biologist (IAAB), Hyderabad, Publication: 2-50p.

[8] Krishnamoorthy G.S., Rajalakshmi and D. Sakthivel (2007): Diversity of plankton in Mangrove areas of Puducherry, India. Journal of Aquatic Biology, 22: 45-48p.

[9] Laskar H.S. and S. Gupta (2009): Phytoplankton diversity and dynamics of Chatla floodplain Lake, Barak Valley, Assam, Northeast India- A seasonal study. Journal of Environmental Biology, 30: 1007 $1012 \mathrm{p}$.

[10] Mathivanan V., P. Vijayan, S. Sabhanayakam and O. Jeyachitra (2007): An assessment of plankton population of Cauvery River with reference to pollution. Journal of Environmental Biology, 28(2): 523-526p.

[11] Mishra A., S.K. Chakraborty, A.K. Jaiswar, A.P. Sharma, G. Deshmukhe and M. Mohan (2010): Plankton diversity in Dhaura and Baigul reservoirs of Uttarakhand. Indian Journal of Fisheries, 57(3): 19$27 \mathrm{p}$.

[12] Rajashree G, Panigrahy R.C. (1993): Monthly variations of some hydrographic parameters in the Rushikulya estuary east coast of India. Mahasgar Bulletin National Institute Oceanogr., 26(2):73-85p.

[13] Ramesha M.M. and Sophia S. (2013): Species composition and diversity of plankton in the River Seeta at Seetanadi, the Western Ghats, India. Research Article, Vol. 12(08): 20-27p.

[14] Rashid H. U. and A.K. Pandit (2008): Ecology of plankton community of river Sindh in Kashmir Himalaya. Journal of Himalayan Ecology Sustian. Dev., Vol. 3, 11-22p.

[15] Sharma, S., Singh K., Prajapati R., Solnki C.M., Sharma D., Sengupta T., Gandhi T., Chouhan M., and Vyas A. (2011): Diversity and seasonal abundance of phytoplankton of River Narmada Madhya Pradesh (India). World Rural Observations, 3(2): 14-28.

[16] Sharma N.K. and S. Bhardwaj (2011): An assessment of seasonal variation in phytoplankton community of Mahi River (India). Journal of Gene Conserve, No. 40, 154-164p.

[17] Shinde S.E., T.S. Pathan and D.L. Sonawane (2012): Seasonal variations and biodiversity of phytoplankton in Harsool-Savangi dam, Aurangabad, India. Journal of Environmental Biology, 33: 643$647 \mathrm{p}$.

[18] Suresh B., S. Manjappa and B.T. Puttaiah (2011): Seasonal variation of phytoplankton in Tungabhadra River near Harihar- Karnataka. Research Journal of Biological Sciences, Vol. 6(2): 65-68p.

[19] Tripathy A.K., Pandey S.N. (1990): Water Pollution. New Delhi: Ashish Publishing 326p. 


\section{International Journal of Science and Research (IJSR) \\ ISSN (Online): 2319-7064}

Index Copernicus Value (2013): 6.14 | Impact Factor (2014): 5.611

[20] Trivedy R.K. and Goel P.K. (1986): Chemical and Biological Methods for Water Pollution Studies. Environmental Publication, Karad, 250p.

[21] Vasanthkumar B. and Vijaykumar K. (2011): Diurnal variation of Physico-chemical properties and primary productivity of phytoplankton in Bhima River. Recent Research in Science and Technology, 3(4): 39-40p.

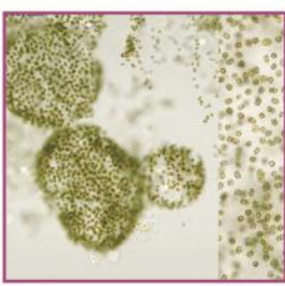

Microcystis Sp.

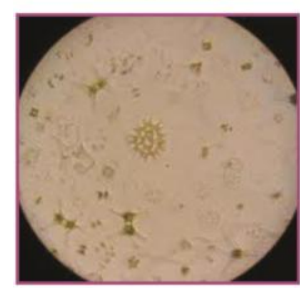

Pediasrum Sp.

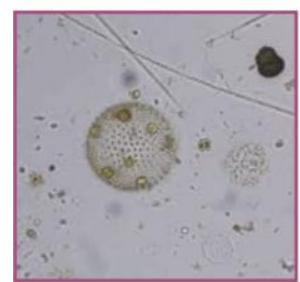

Volvox Sp.

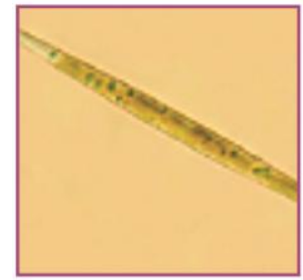

Synedra Sp.

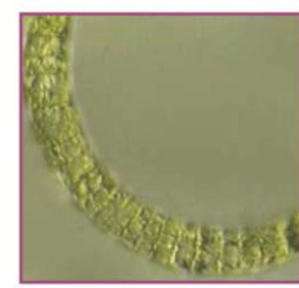

Spirulina Sp.

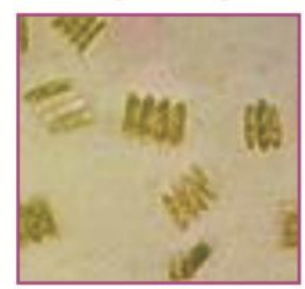

Scenedesmus Sp.

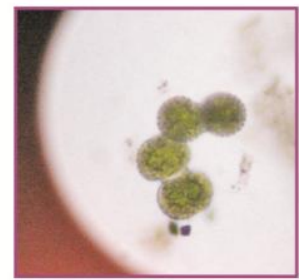

Protococcus Sp.

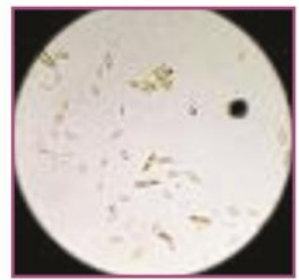

Navicula Sp.

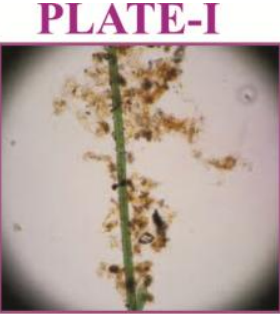

Oseillatoria Sp.

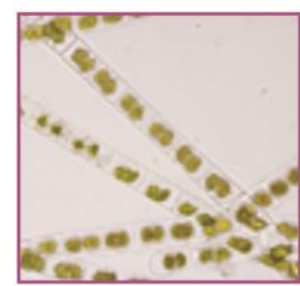

Zygnema Sp.

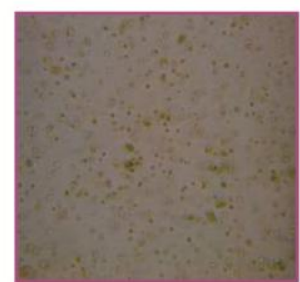

Chlorulla Sp.

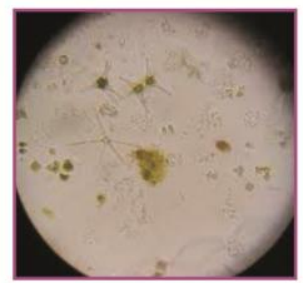

Asterianella Sp.

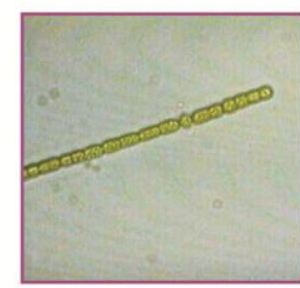

Anabaena Sp.

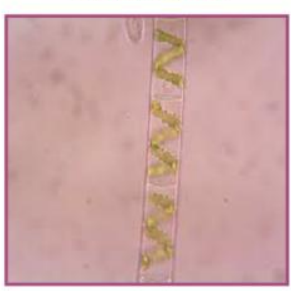

Spirogyra Sp.

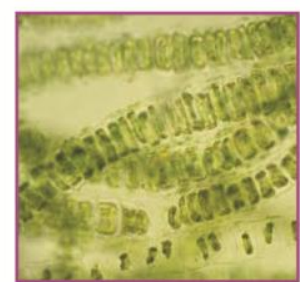

Ulothrix Sp.

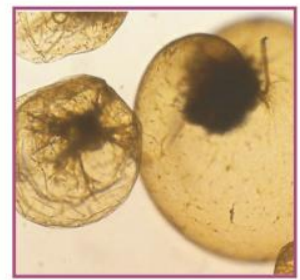

Diatom Sp.

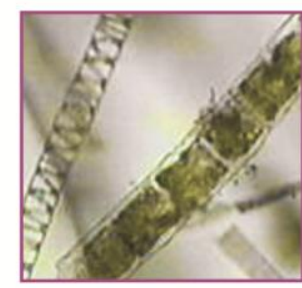

Oedogonium Sp.

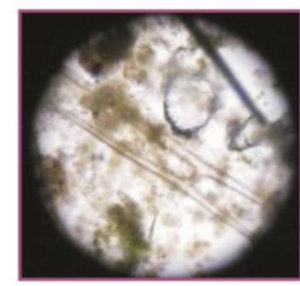

Closterium Sp.

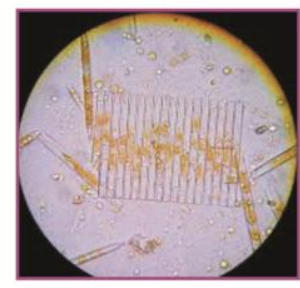

Fragillaria Sp.

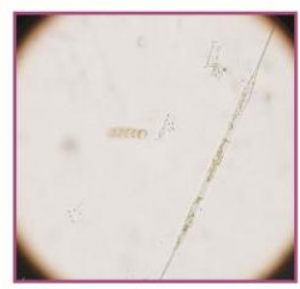

Rhizosolenia Sp. 


\section{International Journal of Science and Research (IJSR) \\ ISSN (Online): 2319-7064}

Index Copernicus Value (2013): 6.14 | Impact Factor (2014): 5.611

Table 1: Shows List of Phytoplankton identified during the study period 2010-2011

\begin{tabular}{|c|c|c|c|c|}
\hline Sr. No. & Class/Order/Geneus & Station-I & Station-II & Station-III \\
\hline I & Cyanophyceae & & & \\
\hline $\mathbf{A}$ & Chroococcales & & & \\
\hline 1 & Microcystis Sp. & + & - & + \\
\hline 2 & Spirulina Sp. & + & - & + \\
\hline $\mathbf{B}$ & Oscillatoriales & & & \\
\hline 3 & Oscillatoria $S p$. & + & - & + \\
\hline $\mathbf{C}$ & Nostocales & & & \\
\hline 4 & Anabaena Sp. & + & - & + \\
\hline II & Chlorophyceae & & & \\
\hline D & Oedogoniales & & & \\
\hline 5 & Oedogonium Sp. & + & + & + \\
\hline $\mathbf{E}$ & Chlorococcales & & & \\
\hline 6 & Pediastrum Sp. & - & + & - \\
\hline 7 & Scenedesmus Sp. & - & + & + \\
\hline $\mathbf{F}$ & Zygnematales & & & \\
\hline 8 & Zygnema Sp. & + & - & + \\
\hline 9 & Spirogyra Sp. & + & + & + \\
\hline 10 & Closterium Sp. & + & - & - \\
\hline $\mathbf{G}$ & Chlamydomonadales & & & \\
\hline 11 & Volvox Sp. & + & & \\
\hline 12 & Protococcus $S p$. & + & + & + \\
\hline $\mathbf{H}$ & Chlorellales & & & \\
\hline 13 & Chlorella Sp. & + & - & + \\
\hline $\mathbf{I}$ & Ulotrichales & & & \\
\hline 14 & Ulothrix Sp. & + & - & + \\
\hline III & Bacillariophyceae & & & \\
\hline $\mathbf{J}$ & Pennales & & & \\
\hline 15 & Fragillaria Sp. & - & + & + \\
\hline 16 & Synedra Sp. & - & - & + \\
\hline 17 & Navicula Sp. & & & \\
\hline $\mathbf{K}$ & Fragilariales & & & \\
\hline 18 & Asterianella Sp. & - & + & + \\
\hline 19 & Diatom $S p$. & + & + & + \\
\hline $\mathbf{L}$ & Rhizosoleniales & & & \\
\hline 20 & Rhizosolenia Sp. & + & + & + \\
\hline
\end{tabular}

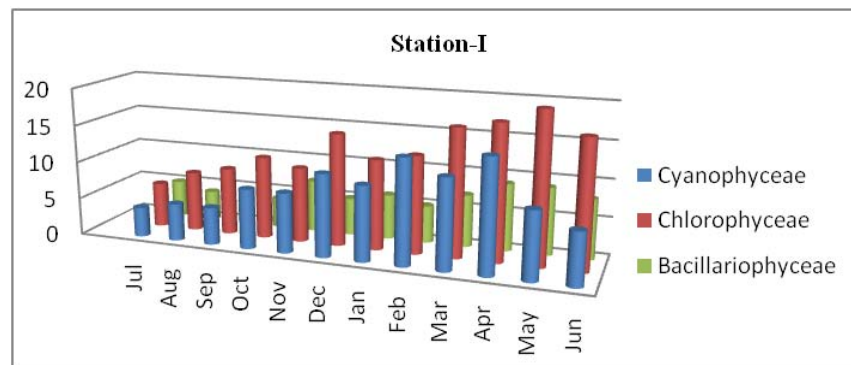

Figure 1: Shows Monthly variation of Phytoplankton at Station-I

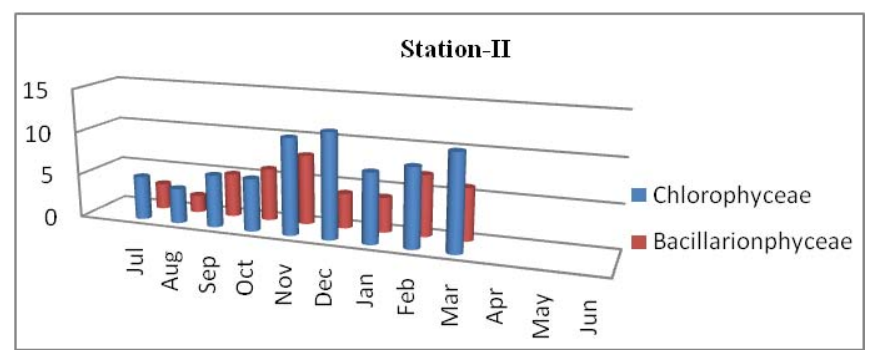

Figure 2: Shows Monthly variation of Phytoplankton at Station-II

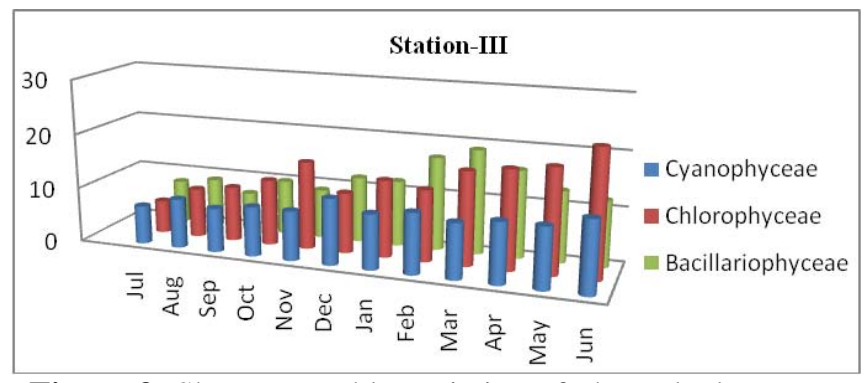

Figure 3: Shows Monthly variation of Phytoplankton at Station-III

Volume 4 Issue 12, December 2015 